\title{
When Daddy Wants Out: The Issue of Paternity
}

Jane C. Murphy

University of Baltimore School of Law, jmurphy@ubalt.edu

Cheri Wyron Levin

University of Baltimore School of Law, clevin@ubalt.edu

Follow this and additional works at: http://scholarworks.law.ubalt.edu/all_fac

Part of the Family Law Commons, and the Juvenile Law Commons

\section{Recommended Citation}

Jane C. Murphy \& Cheri Levin, When Daddy Wants Out: The Issue of Paternity, 33 Md. B.J. 10 (2000)

This Article is brought to you for free and open access by the Faculty Scholarship at ScholarWorks@University of Baltimore School of Law. It has been accepted for inclusion in All Faculty Scholarship by an authorized administrator of ScholarWorks@University of Baltimore School of Law. For more information, please contact snolan@ubalt.edu. 
Published bimonthly by the

Maryland State Bar Association, Inc.

The Maryland Bar Center

520 W. Fayette St.

Baltimore, Maryland 21201

Telephone: (410) 685-7878 (800) $492-1964$

Web site: www.msba.org Executive Director - Paul V. Carlin

Editor-Janet Stidman Eveleth

Assistant to Editor - Ruth E. Ballard

Design - Blue Sky Design

Art Direction - Brian Michael Lawrence

Advertising Sales - Network Publications

Subscriptions: MSBA members receive THE MARYLAND BAR JOURNAL as $\$ 20$ of their dues payment goes to publication. Others, $\$ 42$ per year.

POSTMASTER: Send address change to THE MARYLAND BAR JOURNAL, 520 W. Fayette St., Baltimore, MD 21201.

The Maryland Bar Journal welcomes articles on topics of interest to Maryland attorneys. All manuscripts must be original work, submitted for approval by the Special Committee on Editorial Advisory, and must conform to the Journal style guidelines, which are available from the MSBA headquarters. The Special Committee reserves the right to reject any manuscript submitted for publication

Advertising: Advertising rates will be furnished upon request. All advertising is subject to approval by the Editorial Advisory Board.

Editorial Advisory Board

Elizabeth M. Kameen, Chair

Mimi Azrael

Michael D. Berman

Courtney Blair

Ann Norman Bosse

Timmerman Tepel Daugherty

Marcella A. Holland

Louise A. Lock

Nancy J. Malir

Victoria Henry Pepper

A. Eric Peltosalo

Mary Langdon Preis

Association Officers (1999-2000)

President-James L. Thompson

President-Elect - Richard H. Sothoron, Jr.

Secretary-James P. Nolan

Treasurer-Harry S. Johnson

\section{ETHICS HOTLINE}

\section{MARCH 2000}

Steven Rosen (301) 699-1400

Thomas A. Wade

(301) 733-6644

Richard Bardos

(410) 576-6533

Prince George's

Washington

Baltimore City

APRIL 2000

Coleen Clemente (410) 848-9151

Thomas E. Lynch, III

(301)698-2304

Hon. Joan Gordon

(41.0) $229-4193$ Baltimore

Haw, Library,
Carroll

Frederick

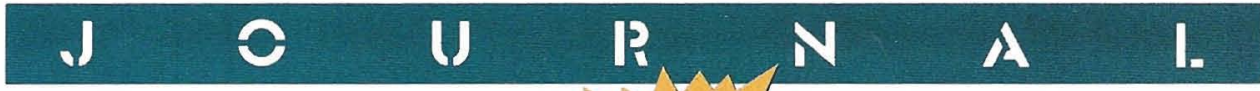

XXXIII • Number 2

March/April 2000
The MARYLAND BAR JOURNAL and its edfitor Janet Stidman Eveleth, have been honcred with a Luminary Aword for Excellence in Publicotions by the Notional Asscolotion of Bor Executives Communication Section.

\section{WHAT ABOUT THE CHILDREN??}

What About Me? The Child's Voice In Court

by Ann N. Sundt

When Daddy Wants Out: The Issue Of Paternity

by Jane C. Murphy and Cheri Wyron Levin

Representing Children in Custody Disputes

by Susan Carol Elgin

Family Court - An Investment In The Future

by Janet Stidman Eveleth

Children: Wards Or Waifs Of The Court?

by Susan Leviton

Adoption in Maryland

by Natalie H. Rees

Laws Protecting Children With Special Needs

by Ellen A. Callegary and Abigail F. Cohen

I Don't Want To Grow Up - The Age Of Majority

by Eric Peltosalo

Children's Rights In Medical Decision-Making

by Catherine M. Brennan

\section{Deceptive Advertising Cases}

54

by W. Lawrence Westcott II

Departments

Attorney Grievance Commission

Unhappy Complainants - Justified or Unjustified - Part One

Ethics Docket

Client's Refusal to Pay Out-of-Pocket Costs

Statements or opinions expressed herein are those of the authors and do not necessarily reflect those of the Maryland State Bar Association, its officers, Board of Governors, the Editorial Board or staff. Publishing an advertisement does net imply endorsement of any. product or service offered. 


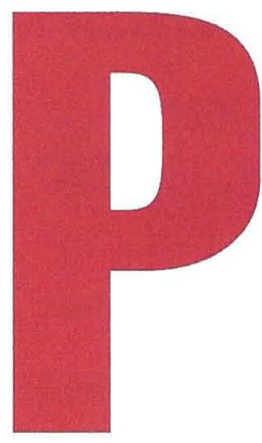

erhaps you've seen the signs along a number of major highways in Maryland. A pregnant Mona Lisa advertising a DNA testing company with the caption "Who's the Daddy?" With the rise in the number of children born out of wedlock in Maryland in the last several decades, paternity testing is becoming routine and family law practitioners are handling more cases in which the father or mother or both are trying to change who is named as the legal father in a paternity or divorce judgment. The law governing such cases has changed substantially since 1995 . This article will guide the practitioner through the changes in the law, describe the need for separate representation of children in many of these cases and provide guidance on effective representation of children in paternity modification proceedings.

\section{Background}

In 1994, the Maryland Court of Appeals issued a widely publicized decision that required two men to make child support payments for children they did not father. Although many lawyers and a few judges commented at the time that the ruling both defied common sense and was unjust, the decision reaffirmed well-established legal principles on the finality of judgments. Tandra S. v. Tyrone W., $336 \mathrm{Md} .303$ (1994) involved a consolidated appeal of two paternity cases in which blood tests, performed years after the judgments were entered, excluded the legal fathers. In reversing the trial courts' orders reopening the paternity judgments, the Court of Appeals ruled that an order declaring paternity was a final judgment subject to revision only in the manner and to the extent that any order is subject to the revisory power of the court. Under Maryland Rule 2-535(b) there must be clear and convincing evidence of fraud, mistake or irregularity before the judgment can be vacated.

Shortly after the court's decision in Tandra S. v. Tyrone W., the General Assembly modified Title 5, subtitle 10 of the Family Law Article, which is generally used to determine paternity of a child born out of wedlock for purposes of establishing responsibility for the support of that child. The statute now provides in pertinent part that "A declaration of paternity may be... set aside... if a blood or genetic test done in accordance with $\$ 5-1029$ of this subtitle establishes the exclusion of

Ms. Murphy is a Professor of Law and Ms. Levin an Adjunct Professor of Law, with the University of Baltimore School of Law.

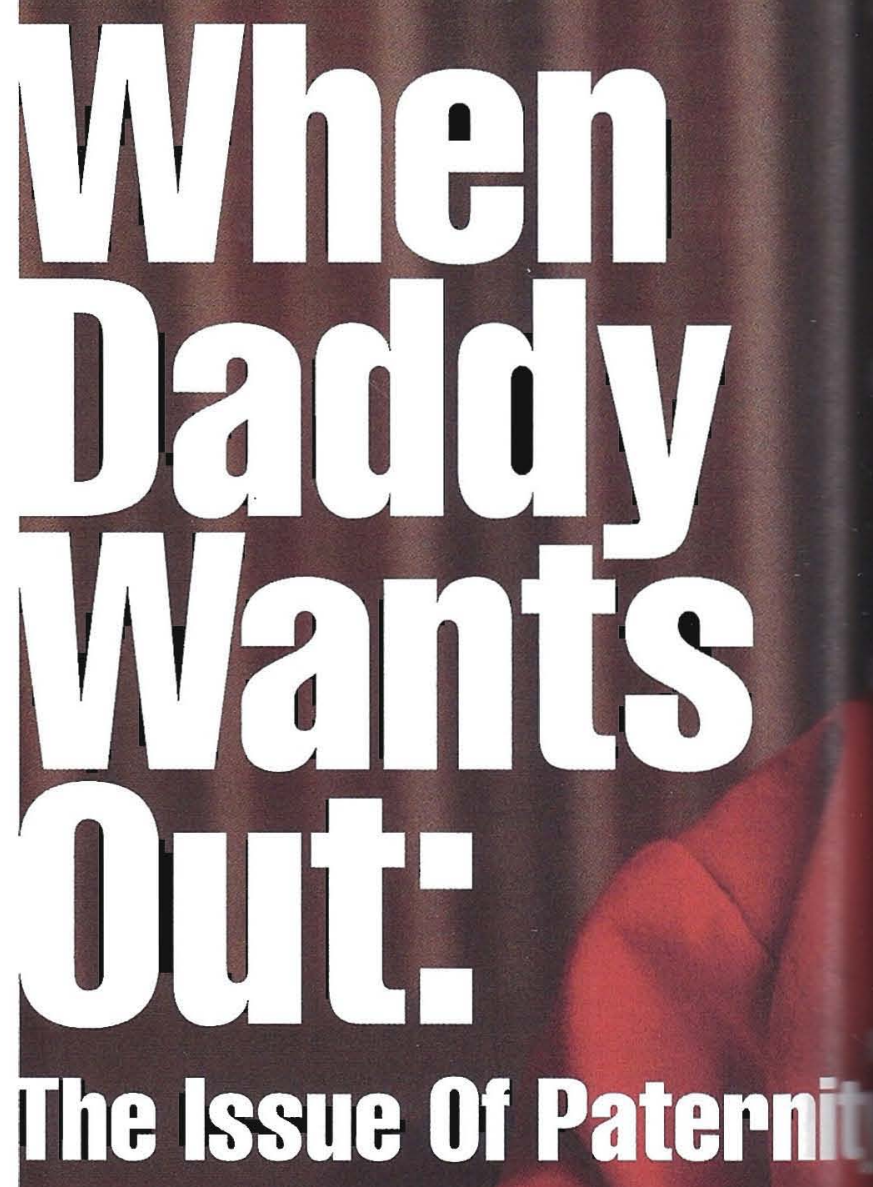


the individual named as father in this order. Family Law Article, §51038(a)(2). The Code also contains a second paternity provision, Estates and Trust Article, \$1-208, which permits an equity court to determine the paternity of a child. This provision is typically used to determine paternity for purposes of inheritance, but has also been deemed the preferred procedure for other situations that arise, such as when two men claim paternity of the same child, Turner $v$. Whisted, $327 \mathrm{Md} .106$ (1992), or where a woman challenges the paternity of her husband of a child born during their marriage, Monroe v. Monroe, $329 \mathrm{Md} .758$ (1993). The latter type of proceeding is affected by the 1995 amendments only to the extent that \$208(b)(1) of the States and Trusts Article incorporates prior judicial determinations of paternity as a method of demonstrating paternity.

At the time the legislation was enacted there was very little debate. The only opposition to the bills came from the lawyers and agencies entrusted with enforcing the child support laws. The increasing cost of governmental support for children had led, in the 1980s and 1990 s, to a variety of legislative mechanisms to find absent fathers. The child support enforcement bureaucracy saw \$5-1038(a)(2) as a potential obstacle to establishing paternity and collecting child support. Despite these concerns, the law passed easily in 1995.

Section 5-1038(a)(2) left a couple of questions open. Does the ability to modify apply to declarations of paternity in divorce judgments? Typically, these findings are nothing more than recitals, based upon the parties' pleadings and/or testimony that certain named children were born of the marriage. Custody may be awarded and support may be ordered, but in the usual case the children's paternity is not actually litigated. Are such findings "declarations of paternity" within the meaning of 55-1038(a) subject to reopening or do the traditional preclusion doctrines - res judicata, collateral estoppel, judicial estoppel, single controversy - apply to paternity findings in divorce decrees?

Another question left open by $\S 5-1038$ is whether setting aside or modifying a declaration of paternity entitles the individual who had been named as the father in the order to recover past payments or be relieved of arrearages? Here the answer seems much clearer. Both Maryland and federal law bar retroactive modification of child support orders, Family Law Article, \$12-104; 42 U.S.C. \$666(a)(9), and this authority has been held to bar recovery of child support paid under a judgment of paternity that is subsequently vacated. Monroe County Department of Social Services, 609 N.Y.S.2d 762 (1994); cf, Krikstan v. Krikstan, 90 Md. App. 473, (1992). 


\section{Need for Separate Representation of Children}

Since the enactment of the amendments, petitions to vacate or modify paternity judgments have been quietly filed throughout the state. The question of when a child needs separate legal representation from his or her parents is the subject of much debate and many law review articles. Some have argued that children have a constitutional right to representation in any proceeding in which the ability to maintain a custodial or legal relationship with a parent is at issue.

While the argument that a child has a liberty interest in the identity of his or her legal father has not been established in Maryland, there are some signs that such an argument might prevail. The Court of Appeals has recently heard arguments in a case in which the Court of Special Appeals found a constitutional right for children to participate in termination of parental rights cases where parents have defaulted or consented. In re Adoption/ Guardianship No.67970003,127 Md. App. 33 (1999); In re Adoption/Guardianship No. T97036005 and In re Adoption/Guardianship No. T98097012 (argued Sept. 30, 1999).

The impetus for providing separate representation for children, then, must be grounded in statutory law. Although there is a statutory mandate for separate representation of a child in Child In Need of Assistance cases (Courts \& Judicial Proceedings Article, \$3-821), the decision to appoint an attorney in a contested custody, visitation or child support case is discretionary. Family Law Article, \$1-202. Because reopening paternity judgments will necessarily affect the obligation to pay child support, \$1-202 provides the court with discretionary authority to appoint an attorney in these proceedings if the court chooses to exercise its discretion on the motion of one of the parties or on its own motion.

Despite the regular practice of appointing attorneys in contested custody cases, a survey of the largest jurisdictions in Maryland reveals that, with the exception of Baltimore City, courts rarely appoint attorneys for children in paternity modification proceedings. Judges and lawyers in these cases apparently assume that either the child has no independent interest in changing or preserving a paternity judgment or, whatever the child's interests are, those interests are represented by the state or the mother (who is often unrepresented by counsel).

Our experience has demonstrated that in these cases, like custody cases, the interests of the adults may not be the same as the child's. For example, in many cases the mother is willing to agree to vacate the paternity judgment. Even if she believes the legal father is the biological father, she may not be interested in any support from him. She has supported the child herself without any help from the legal father or is not likely to receive his support because the state has provided benefits.

In other cases where there is genuine doubt as to the legal father's biological link, she may agree it is only fair to let the legal father "off the hook," or she may believe the legal father voluntarily became the "psychological father" to the child but the legal father may have intimidated or regularly harassed the mother about "setting the record straight." The mother may acquiesce under pressure from the legal father or because she feels she and her child would be better off without the negative presence of the legal father.

The child, on the other hand, may have an interest in preserving the paternity decree, even if there is no biological link. In cases where no other father is likely to be identified or established legally, the child may be rendered fatherless by the proceeding. This may result in emotional harm where some emotional attachment to the legal father has been established. In addition, given the loss of the right to support, governmental benefits and the right to inherit, the child may also suffer financial harm from vacating the paternity decree. In these circumstances, appointing separate counsel for the child would provide a "voice" for the child in the proceeding. As the Court of Special Appeals stated in the custody context:

We are most concerned that a fiveyear-old child has been the subject of litigation for over on-fourth of his life and has yet to see an end to it. We are also concerned that during the four days of testimony before the Master, the Master never spoke to the child, never heard from a truly objective witness and did not have the input of someone who would speak on behalf of the child. Since no other testimony was offered, the hearing before the Chancellor suffered from the same deficiency. This deficiency should be remedied by our direction that separate counsel be appointed for [the child].

The potential adverse consequences of failing to appoint an attorney for the child in proceedings brought under $\$ 5-1038$ (a)(2) were demonstrated in the recent Court of Special Appeals decision in Tyrone W. v. Danielle R., et al., 1999 WL 1085663 (Md. App. filed Dec. 3, 1999). In that case, the court reviewed a trial court decision involving the same putative father, Tyrone Wilson, who was before the Court of Appeals in the 1994 case Tandra S. V. Tyrone W. In the 1999 case, the court interpreted the 1995 amendment to $\$ 5-$ 1038 and held that Mr. Wilson is entitled to genetic testing to determine if he is the biological father of a ten-year-old boy. The child was not represented before either the trial or appellate courts. Without any discussion of whether the taking of blood tests would be in the best interest of the child, the court held that:

[B]y amending F.L. \$5-1038(a) as it did in 1995, the Legislature intended that blood or genetic testing under F.L. \$5-1029 not only may be requested by an alleged father, and upon such request shall be ordered, before a declaration of paternity, but also may be requested by an adjudged father, and upon such request shall be ordered, after a declaration of paternity, upon a preliminary showing of good cause to believe that the requested tests will establish the necessary factual predicate for the court to exercise its revisory power under F.L. $\$ 1038(a)(2)(i)(2)$.

Id. at 19 .

The court further found that good cause was satisfied in this case by Mr. Wilson's testimony that he believed the mother had a sexual relationship with another man at the time of the child's conception. The mother testified that the relationship was at a different time and she was "positive that Tyrone is T.R.'s biological father." Id. at 6 . Apart from a reference to the adjudged father's claim that he and the child were not close, there was no discussion of the impact of the blood tests on the child. If the child in that case had been represented, counsel could have developed both factual and legal bases for application of the appropriate standards - best interests of the child - for determining whether blood tests should have been ordered. 


\section{The Role of the Child's Attorney}

Once an attorney has been appointed, a number of issues may arise that are common to other contexts in which the client is a child. First, attorneys should make certain that the order appointing them clarifies the role the attorney is to play in the case. Attomeys representing children can be appointed as advocates for the child's position or to represent what they believe to be the best interests of the child or to waive the child's right to confidentiality under the Nagle v. Hooks doctrine or any combination of these three roles. Paternity decisions do not involve the child's preference in the same way as custody cases. The courts, therefore, are most likely to appoint attorneys to represent the best interests of the child rather than the child's advocate. In any event, counsel should make certain that they are not ordered to undertake potentially conflicting roles.

Other ethical issues that may confront the child's attorney relate to the attorney's obligation to obtain information from and provide information to the child client. The child's young age or, in the case of older children, the attorney's concern about potential emotional trauma from learning about the putative father's effort to terminate the relationship may make it impossible to fully inform the child client about the case. Maryland's Rules of Professional conduct recognize the special circumstances that exist when the client is a child. The comment to Rule 1.4, which governs the lawyer's obligation to communicate with his client, notes that "ordinarily the information to be provided is that appropriate for a client who is a comprehending and responsible adult.

However, fully informing the client according to this standard may be impracticable... where the client is a child." The Comments to Rule 1.14 which deals with clients under a disability cautions that "when the client is a minor... maintaining the ordinary client-lawyer relationship may not be possible in all respects." Thus the rules support the attorney's decision in a paternity case not to interview a child who is either too young or too vulnerable to discuss the specifics of the case.

Once you have been appointed to be the best interest attorney, your task is to formulate a recommendation to the court about whether reopening the paternity decree will be in the best interest of your client. It may seem obvious that your recommendation will be based on the best interests of the child since you were appointed to be the best interest attorney. However, as discussed above, the best interest attorney designation defines the role of the attorney, whereas the best interest of the child standard that we believe the court should apply in cases brought under \$5-1038(a) also defines the role of the court.

\section{The Best Interests of the Child}

In Maryland, the best interest of the child standard has been consistently used by the courts in a variety of matters involving children. For example, the best interest of the child standard has been applied in cases involving custody of children, Ross v. Hoffman, $280 \mathrm{Md}$. 172 (1977); joint custody of children, Taylor 0 . Taylor, $306 \mathrm{Md} .290$ (1985); visitation by parents, North o. North, 102 Md. App. 1 (1994); visitation by grandparents, Fairbanks v. Mc-
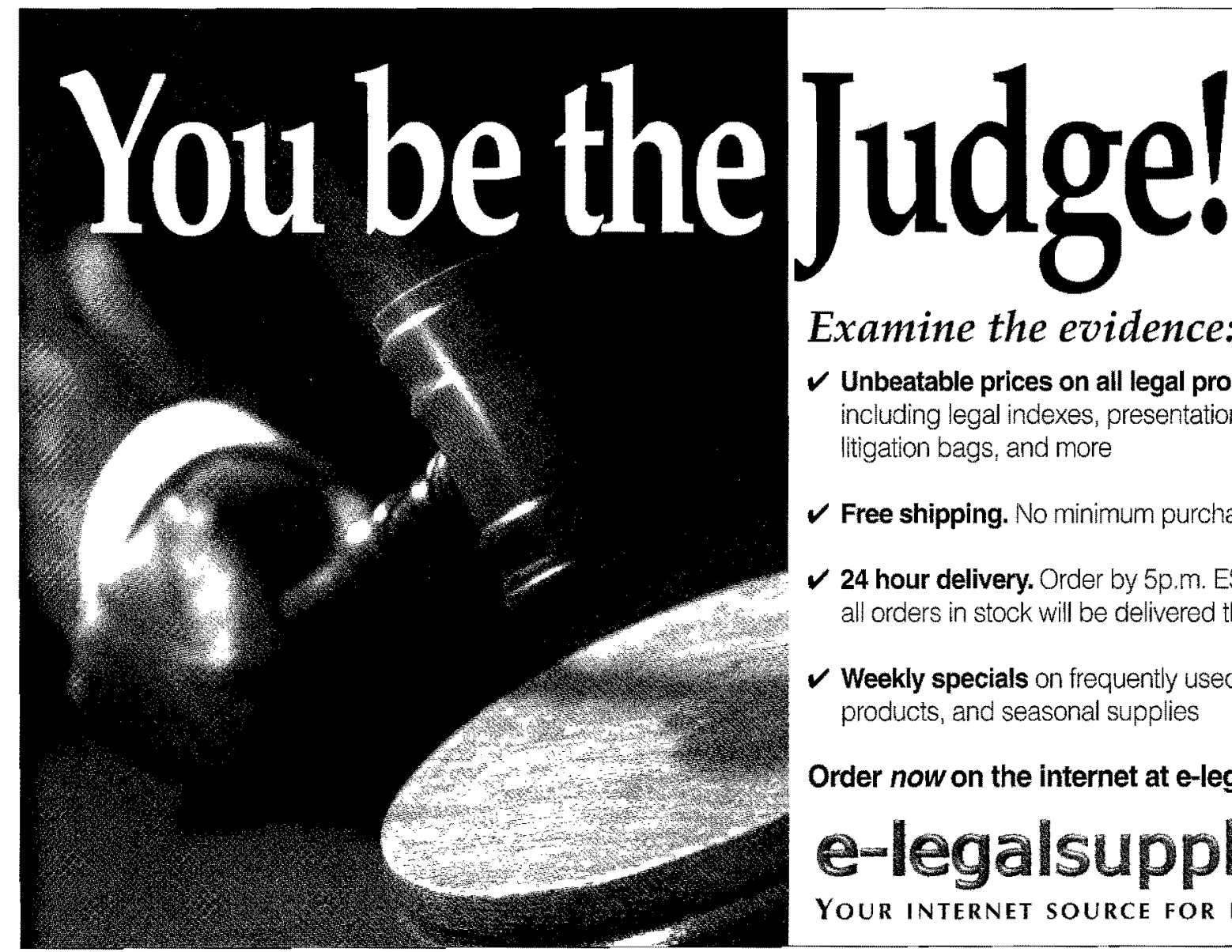

\section{Examine the evidence:}

$\checkmark$ Unbeatable prices on all legal products... including legal indexes, presentation supplies, litigation bags, and more

Free shipping. No minimum purchase required

24 hour delivery. Order by $5 p . m$. EST and all orders in stock will be delivered the next day

$\checkmark$ Weekly specials on frequently used items, new products, and seasonal supplies

\section{Order now on the internet at e-legalsupply.com}

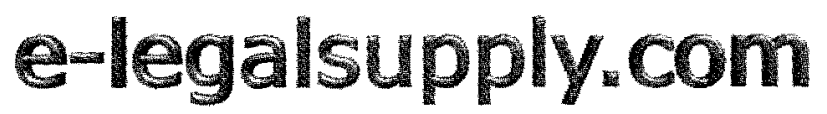

YOUR INTERNET SOURCE FOR LEGAL SUPPLIES 
Carter, 330 Md. 39 (1993); modification of provisions concerning child care and maintenance in separation agreements, Heinmuller v. Heinmuller, $257 \mathrm{Md} .672$ (1970); adoptions of children, In re Adoption/Guardianship No. 10941, 335 Md. 99 (1994); and, in two cases closely related to reopening a paternity decree, a request to establish paternity, Sider v. Sider, 334 Md. 512 (1994) and a request for a blood test, Tumerv. Whisted, 327 Md. 106 (1991). Tumer involved two men, each claiming to be the father of the child in question. The court suggested the possibility that the trial court appoint counsel to represent the child's interest if the court believed that a blood test might be contrary to the child's best interest. In addition, the court in Turner described the facts that the court should consider when it determines what is in the child's best interest in cases of disputed paternity. Id. at 116.

However, the Court of Special Appeals did not apply the best interest of the child standard in determining whether to order blood tests in Tyrone W. $v$. Danielle R., et $a l$., a case in which, as discussed above, the child was not represented by counsel at trial or on appeal. Perhaps when this issue reaches the Court of Appeals, the Court will direct the lower courts to apply the best interest of the child standard. In the meantime, counsel for the child should argue that the best interest of the child standard governs the court's decisions in all issues in disputed paternity cases, including the decision whether to order blood tests.

\section{Investigating the Facts}

One of the most important and potentially time-consuming activities involved in representing children in cases involving efforts to reopen paternity judgments is conducting the factual investigation. As counsel for the child, you must obtain as complete a picture as possible of the child's life, needs, relationships, feelings and future possibilities in order to assess what is in the child's best interest.

In our experience, the factual scenario that most often supports the reopening of a paternity decree is where there is someone other than the legal father who either has assumed the role of father to the child and has been supporting the child financially and emotionally, or who wants to assume that role. This individ-

\section{Salomon Reporting Service}

A hundred years of excellence

in court reporting and legal support service.

The first legal specific videoconference suite opened at the offices of Salomon Reporting Service October 1, 1998.

Call Nancy Banister at Salomon to schedule your FREE demonstration.

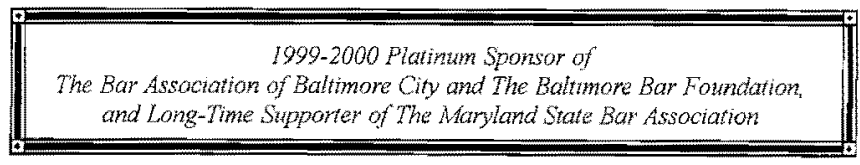

Maryland

$410-539-6760$

Washington D.C.

\section{PRIVATE LONG TERM DISABILITY INSURANCE CLAIMS SOCIAL SECURITY DISABILITY CLAIMS}

\section{- The Law Offices of Greenberg \& Bederman is now accepting referrals for Disability Claims, Denials or Terminations:}

- Employer Sponsored Disability Policies

- Social Security Disability Claims

- Group Plan Disability Policies

- Individual Disability Policies

\section{CONTACT:}

Scott Elkind of the Disability Department (301) 589-2200

ual may be the true biological father, a stepfather, or even someone else.

However, in most cases, particularly those involving older children, there will not be anyone "waiting in the wings" to be the child's father. This makes the assessment of what would be in the child's best interest more complicated. You will need to investigate the child's physical, mental and emotional needs, the child's past relationship with the legal father and particularly whether the child has formed an attachment to the legal father; the stability of the child's family and home environment; and any other facts that affects the child's well-being.

Would reopening and vacating the paternity decree leave the child fatherless for life, with the attendant loss of child support, inheritance rights, and other benefits? Does the child have an emotional attachment to the legal father that would be destroyed by vacating the paternity decree? Does the child have problems that would be exacerbated by finding out that the only father she has ever known does not want to be her father anymore? Obviously each case is different and unique, but these are some of the difficult and troubling questions that you must ponder when determining best interests.

There are various sources of information that will help you in your investigation. At the outset, you probably will not have much information about the case. The court order appointing you to represent the child will most likely be accompanied by only the most recent pleadings filed in the case. Those pleadings will vary depending on who initiated the most recent controversy.

Although there can be a variety of fact patterns, the two most common are either that the state is seeking child support arrearages from the legal father and he answers with a denial of paternity and a request to reopen the paternity decree, or that the legal father has initiated the proceeding by filing a request to reopen the paternity decree.

The court file often is a good source of background information. The file not only contains the history of the entire case, including all of the pleadings, but it also might contain other helpful documents such as correspondence, court orders and case notes. Basic information such as addresses, birth dates and social security numbers might also be in the court file and could prove helpful in locating witness and obtaining documents. 
You should also contact the child's custodian early in the process. The custodian is often the child's natural mother, but the custodian might be a grand parent, another relative or a third party. The custodian can not only provide you with information about the child, but at the outset, the custodian can help evaluate whether you can and should talk to the child.

The initial interview with the child's mother or other custodian, and the child, where prudent, will provide leads for further investigation. Relatives are fertile sources of information, particularly maternal and sometimes paternal grandparents, aunts, uncles, and cousins. Other sources of information might include professionals involved in the child's life, such as teachers and friends of the family.

You should also consider getting information from the legal father or, if represented, from his attorney. Either informal interviews or formal discovery, such as depositions, are possibilities.

As in any case involving a determination of a child's best interest, it might be helpful, depending on the facts of the case, to obtain the assistance of an expert witness to help counsel determine what is in the child's best interests. For example, a psychologist or psychiatrist might be able to shed light on the child's mental and emotional state and the effect that reopening or vacating might have on the child. Likewise, if the child has medical problems, the child's doctor might be able to determine the effect of reopening on the child's physical condition. Cost is a potential impediment to the use of an expert witness, but reduced fees or pro bono assistance might be available.

\section{The Legal Arguments}

In addition to the facts supporting the best interest argument, the legal arguments discussed below might help support your recommendation.

Section 5-1038(a) became effective on October 1, 1995. If the paternity judgment in question was entered prior to October 1,1995 there is an issue as to whether $\$ 5-$ 1032(a) can be applied retroactively to that judgment. Several circuit court judges in Baltimore City have applied \$51038 (a) retroactively and at least one circuit court judge, sitting in Baltimore City, decided in a written, unreported decision that $\$ 5-1038(a)$ could not be applied retroactively. Brown v. Nichols, No. PD396761 (Dec, 3, 1996).

The Court of Special Appeals recently held in Tyrone W.v. Danielle R, et al., that the 1995 amendment to \$5-1038(a) can be applied retroactively on the theory that it is remedial in nature and does not affect vested rights. However, sound arguments can be made that the statute should not be applied retroactively and the issue has not yet come before the Court of Appeals.

If you have concluded that it is not in the best interest of the child to reopen a paternity decree entered prior to October 1,1995 you may want to argue that the statute should not be applied retroactively. The general rule concerning retroactive application of a statute in Maryland is that a statute is presumed to apply prospectively only unless there is a clear legislative intent that the statute apply retroactively. WSSC 0 . Riverdale Fire Co., $308 \mathrm{Md}$. 556, 60-61 (1987). Thus, ascertaining the intent of the Maryland General Assembly is the key to theretroactivity arguments.

It can be argued that since the language of $\$ 5-1038$ (a) is silent as to its application, it shows no legislative intent that the statute be applied retroactively. Likewise, the legislative history contains no indication that the General Assembly intended the statute to apply retroactively. Thus, it can be argued, without legislative intent to the contrary, the statute must be presumed to apply prospectively only.

Whether a statute can be applied retroactively may depend on what type of rights it affects. If a statute affects only procedural rights, and not substantive or vested rights, then the statute can be applied retroactively absent contrary legislative intent. Richardson v. Richardson, $217 \mathrm{Md} .316,320$ (1958). It can be argued that a child's rights to support, inheritance and other benefits are vested rights that would be affected by the retroactive application of the statute.

The paternity judgments that are subject to reopening are final, non-appealable judgments. Retroactive application of a legislative enactment that allows the reopening of a final judgment by the judiciary may violate the separation of powers doctrine by "encroaching on core judicial power." Ex Parte Jenkins, 723 S..2d 649,656 (Ala. 1998). The basis for this potential violation is the notion that the law concerning when a final judgment may be reopened that was applicable at the time the judgment became final is part of the judgment itself and cannot be later changed. However, the fact that the court's authority to reopen a paternity decree un- der \$5-1038(a) is discretionary rather than mandatory may make the separation of powers argument less persuasive.

Section 5-1038(a)(2)(ii) specifically prohibits the modification or setting aside of a declaration of paternity if the "individual named in the order acknowledged paternity knowing he was not the father." The knowledge of the father is a factual issue that must be proven at trial and, if proven, may prevent the reopening of a paternity decree.

There is some question as to the constitutionality of the statute. As noted above, if the statute applies only to declarations of paternity for illegitimate children and not to declarations of paternity for legitimate children in divorce decrees, then there is a potential equal protection. argument. Although the constitutionality of the statute has been raised at the trial court level in Maryland, there have been no rulings on its constitutionality.

\section{Counsel's Recommendation}

Once you have decided what is in the child's best interest, you need to write a report to the court describing your recommendation and the facts and law that support that recommendation. This report should be tailored to the specifics of each case and might include a recitation of the procedural history of the case, a description of counsel's methodology in conducting the factual investigation, a summary of the facts learned from the investigation and the sources of those facts, and an analysis of the facts that support the recommendation. For the legal arguments, the report should also include a statement of the legal questions presented and an analysis of the legal arguments.

At trial, the legal father, who is the moving party, has the burden of proving why it is in the child's best interest to reopen and vacate the paternity decree. Depending on your recommendation, you might be allied with the legal father or you might oppose his position. In any event, you will support your recommendation to the court through witness testimony, documentary evidence, and legal argument.

\section{Conclusion}

Requests to reopen paternity decrees are being filed with increasing frequency. These cases should not go forward without counsel being appointed to represent the children whose paternity is being challenged. do 